\title{
Kelola
}

Jurnal Manajemen Pendidikan

Magister Manajemen Pendidikan

e-ISSN 2549-9661

FKIP Universitas Kristen Satya Wacana

jurnalkelola@gmail.com

\section{Teknik Pengambilan Keputusan Dalam Menentukan Model Manajemen Pendidikan Menengah}

\author{
Muhdi \\ Manajemen Pendidikan \\ Universitas PGRI Semarang \\ muhdi@upgris.ac.id \\ Nurkolis \\ Manajemen Pendidikan \\ Universitas PGRI Semarang \\ nurkolis@upgris.ac.id \\ Suwarno Widodo \\ Pendidikan Kewarganegaraan \\ Universitas PGRI Semarang \\ suwarno61widodo@yahoo.com
}

\begin{abstract}
The main problem in this research is how the model of secondary education management in Central Java Province. Issues divided into a) what are the expectations of various parties regarding the transfer of secondary education management, $b$ ) how are the challenges of various parties related to the transfer of secondary education management, and c) which management model is most effective for managing secondary education in Central Java Province. This research is descriptive qualitative. Data collection through FGD was recorded with video and government policies related to secondary education. The number of informants is nine people. Research data is processed using qualitative research software, NVivo 11 Plus for Windows. The study was conducted over three months from October to December 2016. The results were a) some expectations: improving the quality of education, improving access and equity of education, improving teacher welfare and promoting professionalism. teacher; b) some of the challenges faced: the province will ignore the welfare of non-civil servant teachers and reduce the free education of secondary education; c) the most effective model is co-administration. It is recommended that the government immediately make government regulations on the management of secondary education. At the provincial level was directly made education policy. East Java provincial government has now chosen alternative "based region" in six regions of former residency in Central Java. This alternative needs to be tested for its effectiveness, if it is not effective then it is advisable to use co-administration.
\end{abstract}

Keywords: secondary education, model of secondary education management, co-administration, decision making

\section{Article Info}




\section{PENDAHULUAN}

Sejak berlakunya Undang-Undang Nomor 23 tahun 2014 tentang Pemerintahan Daerah maka terjadi pergeseran pembagian kewenangan dalam urusan pendidikan menengah dari pemerintah kabupaten atau kota ke pemerintah provinsi. Berdasar UndangUndang No. 22 tahun 1999 tentang Pemerintahan Daerah yang diperbaharui beberapa kali dan terakhir dengan UndangUndang No. 23 tahun 2014, urusan pendidikan menengah menjadi kewenangan pemerintah kabupaten atau kota. Dalam UU No. 23 tahun 2014, pendidikan merupakan urusan pemerintahan konkuren wajib terkait dengan pelayanan dasar yang menjadi kewenangan pemerintah daerah sebagaimana tertuang pada pasal 12.

Menurut UU No. 23 tahun 2014 tentang Pemerintahan Daerah, urusan pemerintahan dibagi menjadi 3 yaitu: urusan absolut, urusan konkuren, dan urusan umum. Urusan absolut sepenuhnya menjadi urusan pemerintah pusat. Urusan umum menjadi kewenangan presiden sebagai kepala pemerintahan. Urusan konkuren adalah urusan yang dibagi antara pemerintah pusat, pemerintah daerah provinsi, dan pemerintah daerah kabupaten atau kota. Urusan konkuren terdiri dari urusan wajib dan urusan pilihan. Urusan wajib terkait dengan pelayanan dasar dan bukan pelayanan dasar. Pendidikan merupakan pelayanan dasar yang menjadi urusan konkuren wajib.

Pada lampiran UU No. 23 tahun 2014 tertuang pembagian urusan pemerintahan konkuren antara pemerintah pusat, pemerintah provinsi, dan pemerintah kabupaten atau kota. Terdapat pembagian urusan pemerintahan bidang pendidikan yang mencakup enam sub urusan yaitu: manajemen pendidikan, kurikulum, akreditasi, pendidik dan tenaga kependidikan, perizinan pendidikan, serta bahasa dan sastra. Fokus penelitian ini hanya terkait dengan sub urusan manajemen pendidikan.

Dalam sub urusan manajemen pendidikan, pemerintah pusat memiliki kewenangan menetapkan standar nasional pendidikan dan pengelolaan pendidikan tinggi. Pemerintah provinsi memiliki kewenangan mengelola pendidikan menengah dan mengelola pendidikan khusus. Sementara itu pemerintah kabupaten atau kota memiliki kewenangan mengelola pendidikan dasar, mengelola pendidikan usia dini, dan mengelola pendidikan nonformal.

Berdasarkan UU Pemerintahan Daerah terbaru, manajemen pendidikan menengah yaitu SMA dan SMK kewenangannya dipindahkan dari pemerintah kabupaten atau kota ke pemerintah provinsi. UU No. 23 tahun 2014 ini mulai diberlakukan tanggal 1 Januari 2017, sehingga belum ditemukan penelitian yang relevan. Oleh karena itu penting untuk dilakukan penelitian tentang "model manajemen pendidikan menengah”, khususnya di Provinsi Jawa Tengah.

Masalah utama dalam penelitian ini adalah "bagaimanakah model manajemen pendidikan menengah di Provinsi Jawa Tengah?" yang dirinci menjadi: a). bagaimanakah harapan pengalihan pengelolaan pendidikan menengah, b). bagaimanakah tantangan pengalihan pengelolaan pendidikan menengah, dan c). bagaimanakah model manajemen pendidikan menengah yang efektif di Provinsi Jawa Tengah?

Seluruh pemerintah provinsi di Indonesia pada akhir tahun 2016 harus membuat keputusan terkait model manajemen pendidikan menengah yang paling tepat di wilayahnya. Permasalahan ini harus segera dipecahkan dengan memilih model manajemen apa yang paling tepat. Oleh karena itu dalam menentukan model manajemen yang paling tepat dan efektif diperlukan teknik pengambilan keputusan yang sesuai.

Menurut Drummond (1993) pengambilan keputusan adalah usaha untuk menciptakan kejadian-kejadian masa depan. Sementara itu Harrison (1992: 5) berpendapat bahwa pengambilan keputusan adalah proses mengevaluasi berbagai alternatif yang berhubungan dengan tujuan individu atau organisasi. Pengambilan keputusan erat kaitannya dengan upaya untuk memecahkan 
masalah atau potensi masalah yang dihadapi seseorang atau organisasi.

Selanjutnya Drummond mengatakan bahwa keputusan yang baik terjadi jika pengambil keputusan sepenuhnya mengerti latar belakang, tujuan dan sasaran, alternatif penyebab tindakan, serta konsekuensikonsekuensi yang mungkin timbul dari keputusan. Namun keputusan yang dibuat dengan baik belum tentu menjadi keputusan yang efektif.

Menurut Vroom dan Jago sebagaimana dikutip Hoy dan Miskel (2014) keputusan yang efektif bergantung pada tiga hal yaitu kualitas keputusan, penerimaan bawahan, dan ketepatan waktu. Keputusan dikatakan berkualitas jika mampu memecahkan masalah yang dihadapi seseorang atau organisasi. Keputusan yang efektif juga ditunjukkan dengan tidak adanya resistensi pada pelaksana dan pihak-pihak yang terkait langsung dengan keputusan. Akhirnya keputusan yang efektif terjadi bila dekat dengan waktu terjadinya permasalahan yang akan dipecahkan. Artinya keputusan yang efektif adalah keputusan yang dibuat dengan baik dan dapat diimplementasikan dengan baik pula.

Proses pengambilan keputusan yang efektif menuruf Harrison (1992: 24) dapat dilihat pada gambar 1 .

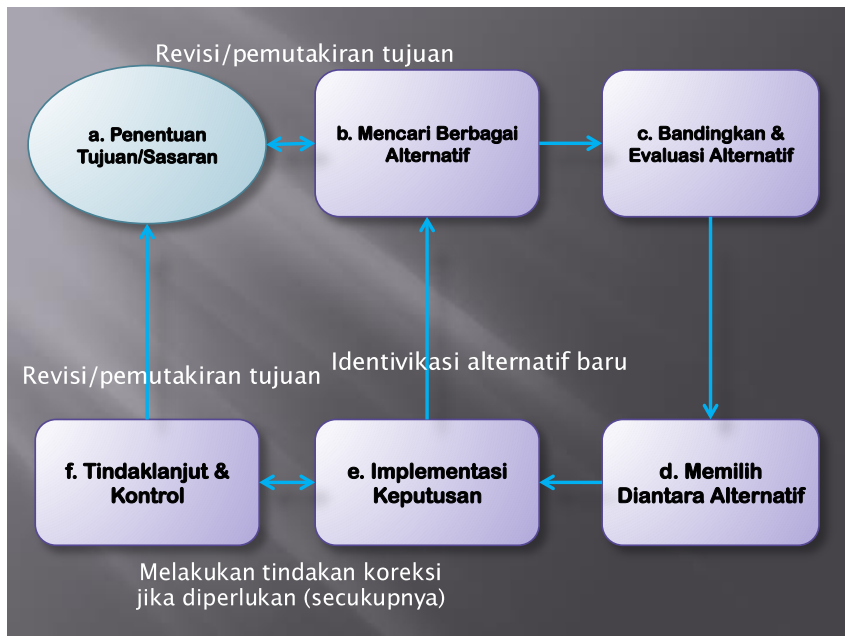

Gambar 1. Proses Pengambilan Keputusan

Dalam studi tentang pengambilan keputusan dikenal tiga teori yaitu: teori probabilitas, teori utilitas, dan teori permainan (Harrison, 1992: 219-252). Teori probabilitas didasarkan pada peluang hasil bila dalam periode waktu tertentu suatu kejadian diulangulang. Teori utilitas didasarkan pada seberapa besar manfaat yang diperoleh dari sebuah kejadian yang dipilih. Teori permainan digunakan apabila seorang pengambil keputusan tidak mengetahui sutiasi dan kondisi yang riil, dan biasanya digunakan dalam situasi konflik.

Berdasarkan teori pengambilan keputusan tersebut, terdapat beberapa teknik pengembilan keputusan yang merupakan perpaduan dari teori probabilitas dan teori utilitas.

Pertama, teknik pengambilan keputusan expected values. Teknik ini mempertimbangkan kemungkinan munculnya kejadian dan kemungkinan hasil. Kombinasi dua kemungkinan tersebut menghasilkan nilai moneter yang diharapkan. Kejadian yang memiliki nilai moneter paling tinggi akan menjadi pilihan seorang pengambil keputusan.

Kedua, teknik pengambilan keputusan payoff tables. Teknik ini memperhitungkan alternatif kejadian yang muncul dan alternatif situasi yang menguntungkan atau tidak mengungtungkan. Kombinasi kedua alternatif tersebut akan memberikan gambaran hasil moneter yang berbeda-beda. Kejadian yang 
memberi hasil maksimal akan menjadi pilihan seorang pengambil keputusan untuk memecahkan masalah.

Ketiga, teknik pengambilan keputusan decision trees. Keputusan dilakukan dengan cara membuat anatomi sebuah pohon yang terdiri dari titik dan cabang. Penilaian kejadian dimulai dari titik dengan melewati cabang, setiap cabang mengambarkan kemungkinan keberhasilan sebuah kejadian. Semakin besar kemungkinan keberhasilannnya akan menjadi pilihan seorang pengambil keputusan.

Berdasarkan ketiga teknik pengambilan keputusan tersebut, teknik payoff tables dinilai yang paling cocok dengan fokus penelitian ini. Alternatif kejadian keputusan ada empat yaitu: manajemen terpusat di kantor provinsi, manajemen dengan membuka kantor di setiap kabupaten atau kota, manajemen dengan membuka enam Unit Pelaksana Pendidikan (UPP) di setiap eks karesidenan, dan manajemen dengan bekerjasama dengan kantor dinas kabupaten atau kota untuk membentuk tugas pembantuan.

Situasi keputusan yang bernilai positif atau negarif dikaitkan dengan enam kesiapan yaitu: ketersediaan sarana dan prasarana yang memadai, ketersediaan sumber daya manusia yang kompeten, untuk menjaga hubungan kerja sama dengan pemerintah kabupaten atau kota, untuk mengakomodasi keinginan kabupaten atau kota guna berpartisipasi dalam pengelolaan pendidikan menengah, efisiensi operasional pendidikan, dan kemudahan operasional pendidikan.

Kombinasi dari alternatif kejadian dan situasi keputusan akan dihitung dengan menambahkan nilai positif dan mengurangkan nilai yang negatif. Alternatif kejadian yang memiliki nilai positif paling tinggi yang akan diambil sebagai alternatif terpilih karena memiliki kelayakan paling tinggi untuk dapat berhasil bila dioperasikan. Artinya model yang terpilih adalah yang memiliki efektivitas paling tinggi dan kemungkinan berhasilnya juga paling tinggi.

\section{METODE PENELITIAN}

Penelitian ini menggunakan pendekatan kualitatif jenis deskriptif. Pengumpulan data melalui focus group discussion (FGD) dengan sembilan (9) orang ahli manajemen pendidikan yang direkem dengan video. Data dilengkapi dengan sepuluh (10) undang-undang dan kebijakan pemerintah terkait manajemen pendidikan. Rekaman video dari hasil FGD ditranskripsi secara verbatim sesuai dengan aslinya untuk mendukung data penelitian sesuai dengan fokus yang diinginkan. Analisis data penelitian ini menggunakan software NVivo 11 Plus. Langkah-langkah analisis kualitatif adalah sebagai berikut: a) melakukan FGD pada tanggal 28 Desember 2016 yang direkam dengan video dan mengunduh file PDF UU dan kebijakan pemerintah yang relevan dengan pengelolaan pendidikan menengah; b) data mentah yang diperoleh diimpor ke software NVivo 11 Plus untuk dibuat nodes dan cases, b) nodes dan cases selanjutnya dilakukan coding c) akhirnya menarik kesimpulan dari temuan berdasarkan nodes dan cases. Untuk menentukan model manajemen yang tepat dibantu dengan teknik pengambilan keputusan menggunakan payoff table yang dimodifikasi.

\section{HASIL DAN PEMBAHASAN \\ Harapan Pengalihan Manajemen \\ Pendidikan Menengah}

Harapan stakeholders pendidikan terutama dari pemerintah provinsi bisa berjalan dengan lancar sesuai dengan target waktu yang telah ditentukan oleh pemerintah pusat. Pemeritah provinsi menyatakan siap untuk mengelola pendidikan menengah, dan tidak ada satupun pejabat provinsi yang resisten apalagi menolak pengalihan pengelolaan pendidikan menengah dari pemerintah kabupaten atau kota.

Harapan yang baik juga disampaikan oleh para pengamat pendidikan, akademisi, kepala sekolah, dan guru bahwa setelah dikelola pemerintah provinsi maka mutu pendidikan menjadi lebih baik, dan tingkat kesejahteraan guru termasuk di dalamnya gaji guru non PNS menjadi lebih baik. 
Peningkatan mutu dan pemerataan akses pendidikan menengah menjadi harapan banyak pihak ketika pendidikan menengah beralih pengelolaannya dari pemerintah kabupaten atau kota ke pemerintah provinsi. Tidak banyak gubernur yang peduli terhadap peningkatan mutu pendidikan seperti Gubernur Jawa Tengah dan Gubernur Jawa Barat.

Pemerintah Provinsi Jawa Tengah akan membuat gebrakan baru dalam peningkatan mutu pendidikan yaitu memberikan muatan lokal. Ada tiga syarat yang harus dikuasai siswa untuk lulus SMA-SMK yaitu kemampuan berbahasa asing, bisa memainkan alat musik, dan menguasai satu cabang olah raga. Dengan adanya 3 syarat tersebut Gubernur Jawa Tengah menilai akan menjadikan generasi muda memiliki badan sehat, kesimbangan antara otak kiri dan kanan, serta memiliki kemampuan komunikasi yang bagus.

Selama ini terjadi kesenjangan pendidikan menengah antara satu kabupaten atau kota dengan yang lain. Kesenjangan mutu pendidikan menengah terjadi antara kabupaten dengan kota. Misalnya diakui oleh informan dari Dinas Pendidikan dan Kebudayaan Provinsi Jawa Tengah bahwa di Jawa Tengah SMA dan SMK yang bermutu berada di Kota Semarang, Solo, Salatiga, dan Magelang. Sementara itu di kabupaten-kabupaten di pinggiran mutunya belum bisa menyamai mutu pendidikan di perkotaan.

Dari sisi pembiayaan pendidikan yang menjadi pemicu permasalahan akses pendidikan selama ini besarannya juga belum merata. Buktinya ada beberapa kabupaten atau kota yang mampu mengalokasikan Anggaran Pendapatan dan Belanja Daerah (APBD) untuk menggratiskan pendidikan mulai dari pendidikan dasar hingga pendidikan menengah. Sementara itu banyak kabupaten atau kota yang tidak mampu mengalokasikan APBD untuk mendukung pendidikan menengah universal yang akan mengarah ke pendidikan gratis. Di Provinsi Jawa Tengah, beberapa kabupaten atau kota yang telah mengalokasikan anggaran pendidikan hingga pendidikan menengah antara lain Kota Semarang, Kota Salatiga, Kota
Magelang, Kota Surakarta, Kabupaten Karanganyar, dan Kabupaten Sukoharjo.

Namun demikian pendidikan gratis lebih banyak bernuansa politis. Berdasarkan hasil penelitian pendidikan di kota Surakarta belum dapat dirasakan oleh semua lulusan SMP atau yang sederajat, terbukti masih banyak lulusan SMP atau sederajat yang tidak melanjutkan ke sekolah SMA atau SMK. Program pendidikan gratis yang difasilitasi oleh pemerintah belum dapat diterapkan $100 \%$ oleh sekolah karena bantuan dari pemerintah belum dapat mencukupi biaya operasional sekolah sehingga program sekolah gratis di Kota Surakarta belum dapat dirasakan oleh semua masyarakat (Lestari dan Susena, 2014: 1-9).

Penting kiranya Pemerintah Provinsi Jawa Tengah untuk membuat program pendidikan menengah yang meringankan masyarakat terutama yang tidak mampu secara ekonomi. Program semacam ini sebaiknya jauh dari kepentingan politik, yang selama ini dimanfaatkan oleh para calon pimpinan daerah untuk mendapatkan dukungan suara dari para pemilih. Jika ingin membuat program "pendidikan gratis" atau "pendidikan murah dan terjangkau" maka perlu dihitung berapa kebutuhan persiswa pertahun. Agar hasil hitungan akurat dan dapat dipertanggungjawabkan maka perlu mengundang ahli dari perguruan tinggi, pakar pendidikan, atau konsultan pendidikan.

Para guru dan kepala sekolah berharap dengan pengambilalihan pendidikan menengah ini gaji guru semakin baik. Gaji guru PNS akan lebih baik, karena selain mendapat gaji dan tunjangan, para guru juga akan mendapatkan tunjangan profesi dan Tambahan Penghasilan Pegawai (TPP) yang dialokasikan dari APBD Provinsi, seperti di Provinsi Jawa Tengah. Sedangkan harapan guru non PNS, dengan diambil alih oleh pemerintah provinsi kesejahteraan mereka menjadi lebih baik. Selama ini gaji guru non PNS bervariasi antara satu kabupaten dengan kabupaten yang lain. Sebagian guru hanya mengandalkan gaji dari yayasan, sementara yang lainnya juga mendapatkan tunjangan dari APBD kabupaten. 
Setelah dialihkan ke pemerintah provinsi, harapannya para guru non PNS mendapatkan gaji dan tunjangan dari pemerintah provinsi.

Berdasarkan berbagai harapan tersebut, jelas merupakan beban berat bagi pemerintah provinsi untuk mewujudkan harapan menjadi kenyataan. Berbagai harapan tersebut akan menjadi kenyataan apabila didukung oleh sumber daya manusia yang memadai, anggaran yang mencukupi, dan kepemimpinan yang mampu menggerakkan semua sumber daya yang tersedia demi terlaksananya pendidikan menengah yang bermutu.

\section{Tantangan Manajemen Pendidikan Menengah}

Tantanan terbesar pengalihan pengelolaan pendidikan menengah dari pemerintah kabupaten atau kota ke pemerintah provinsi adalah terkait anggaran, baik anggaran untuk membayar tunjangan kepada guru PNS, gaji kepada guru non PNS, dan mendanai biaya operasional sekolah yang selama ini ditanggung oleh pemerintah kabupaten atau kota.

Tantangan dalam pengalihan pengelolaan pendidikan menengah lebih banyak terkait dengan penggajian guru non PNS dan pengalokasian BOSDA (Bantuan Operasional Sekolah Daerah) Provinsi yang diprediksi banyak pihak tidak akan sanggup mencukupi kebutuhan gaji guru non PNS dan pendidikan gratis untuk pendidikan jenjang menengah.

Di provinsi dengan jumlah satuan pendidikan menengah dan jumlah siswa yang banyak seperti di Provinsi Jawa Tengah, akan menghadapi tantangan terkait pengalokasian anggaran gaji guru non PNS. Di Jawa Tengah total non PNS mencapai 16.220 orang. Dengan rincian guru non PNS SMA 3.772 orang, SMK 4.871 orang, tenaga pendidik non PNS SMA 4.266 orang, dan SMK 3.311 orang. Oleh karena itu perlu aturan yang ketat terkait penggajian guru non PNS tersebut seperti disampaikan Kepala Dinas Pendidikan dan Kebudayaan Provinsi Jawa Tengah.

Resistensi stakeholder pendidikan lebih banyak berasal dari pemerintah kabupaten atau kota dan satuan pendidikan. Hal ini dapat dilihat dari adanya penolakan kepala daerah di tingkat kabupaten atau kota hingga penolakan atau kesanksian kepala sekolah dan siswa. Bahkan ada bupati di Provinsi Jawa Tengah yang secara terang-terangan melakukan orasi dihadapan stakeholder pendidikan untuk menolak pengambilalihan pendidikan menengah.

Tantangan yang paling menonjol dalam pengalihan pengelolaan pendidikan menengah ini adalah terkait dengan gaji guru non PNS. Tantangan ini berasal dari kabupaten dan kota yang selama ini telah mengalokasikan APBD untuk gaji guru non PNS. Para guru, kepala sekolah, bahkan bupati khawatir dengan pengalihan pengelolaan ini para guru non PNS akan menurun kesejahteraannya karena tidak dialokasikan gaji non PNS dari APBD Provinsi. Seperti dikemukakan oleh informan FGD (28 Desember 2016) dari Dinas Pendidikan dan Kebudayaan Provinsi Jawa Tengah bahwa gaji guru non PNS menjadi tanggungan penyelenggara pendidikan masing-masing satuan pendidikan yaitu yayasan.

Namun bagi guru non PNS yang memenuhi syarat, yaitu memenuhi kualifikasi pendidikan $\mathrm{S} 1$ dan mengajar 24 jam perminggu maka akan ada kontrak dengan pemerintah provinsi dan mendapatkan gaji dari APBD provinsi. Hal ini juga menjadi kekhawatiran para guru yang selama ini sudah mendapatkan gaji yang cukup besar dari APBD kabupaten, sehingga kalau sumbernya dari APBD provinsi maka gaji guru non PNS akan menurun. Karena UMR provinsi ditentukan berdasarkan UMR kabupaten atau kota yang paling rendah.

Tantangan lain terkait pembiayaan pendidikan adalah BOSDA dari pemerintah kabupaten atau kota yang cukup memiliki kemampuan keuangan seperti di Kota Semarang, Kota Magelang, Kota Surakarta, Kabupaten Sukoharjo, Kabupaten Karanganyar, Kota Cirebon, dan Kabupaten Karawang yang selama ini telah mengalokasikan APBD kabupaten atau kota untuk mendanai pendidikan gratis. Dengan pengalihan ini maka dipastikan BOSDA dari pemerintah provinsi tidak sebesar yang 
diberikan dari pemerintah kabupaten atau kota. Jika saat ini dari pemerintah kabupaten atau kota bisa memberikan BOSDA sebesar Rp. 650.000-Rp. 1 juta persiswa pertahun, maka kemampuan provinsi tidak akan sebesar kemampuan pemerintah kabupaten atau kota. Misalnya di Provinsi Jawa Tengah diprediksi pemerintah provinsi hanya akan mampu memberi BOSDA untuk siswa SMA-SMK Rp. 200.000-Rp. 400.000 saja pertahun.

Kabupaten dan Kota yang telah menaruh perhatian besar terhadap kemajuan pendidikan bakal kecewa jika Pemerintah Provinsi tidak memberikan anggaran yang seimbang dalam pemenuhan anggaran pendidikan menengah. Kota Surabaya merupakan salah satu contoh Kota yang telah mengalokasikan Biaya Operasional Pendidikan Daerah (BOPDA) mulai pendidikan dasar hingga pendidikan menengah. BOPDA telah berdampak positif terhadap peningkatan akses pendidikan bagi masyarakat kota Surabaya dan pelaksanaan pendidikan menengah menjadi lebih baik (Aulia, 2012: 204).

Berdasarkan hasil penelitian, para guru SMK masih mengalami kendala dalam pengembangan keprofesian berkelanjutan. Kendalanya antara lain kendala waktu, dana, usia, sarana prasarana, motivasi, kebijakan pimpinan, dan akses jaringan internet (Sumardjoko dan Prasetyo, 2016: 77-89). Berdasarkan kenyataan ini maka pemerintah provinsi perlu memprogramkan pengembangan keprofesian berkelanjutan bagi guru-guru SMA dan SMK.

Hasil penelitian lain menunjukkan bahwa belum seluruh guru SMK dapat melakukan kegiatan ilmiah terutama menulis karya ilmiah. Sementara itu forum peningkatan kompetensi profesional sangat tinggi pengaruhnya pada pengembangan profesi guru (Suwandi, 2016: 90-100). Sudah sepantasnya Dinas Pendidikan dan Kebudayaan Provinsi Jawa Tengah membuat program pelatihan penulisan karya ilmiah sebagai bagian dari pengembangan keprofesian berkelanjutan guru pendidikan menengah.

\section{Model Manajemen Pendidikan Menengah}

Terdapat tiga (3) teori dalam mengambil keputusan yaitu teori utilitas, teori probabilitas, dan teori permainan. Dalam membuat keputusan dikenal tiga (3) teknik yaitu berdasarkan nilai yang diharapkan (expected values), berdasarkan pertimbangan alternatif dan situasi atau sering disebut payoff tables, dan pohon keputusan. Dari ketiga teknik tersebut, yang cocok untuk membantu mengambil keputusan dalam penelitian ini adalah payoff tables yang dimodifikasi.

Tanggapan informan terkait model pengelolaan pendidikan menengah hanya ada 5 . Tiga diantaranya berpendapat dengan membuka kantor perwakilan provinsi di setiap wilayah. Wilayah ini mencakup beberapa kabupaten atau kota terdapat satu unit pelaksana pendidikan (UPP) untuk menangani pendidikan menengah. Satu informan lebih setuju dibuka di setiap kabupaten atau kota, sedangkan satu orang lagi sependapat bahwa tugas pembantuan bisa diterapkan setelah dilakukan evaluasi unit pelaksana perwilayah dipandang kurang efektif. Sementara itu tidak ada satupun responden yang berpendapat bahwa pengelolaan pendidikan menengah akan efektif bila diurus langsung dari kantor provinsi atau Dinas Pendidikan dan Kebudayaan Provinsi.

Menurut UU No. 23 tahun 2014 tentang Pemerintahan Daerah dijelaskan bahwa tugas pembantuan adalah penugasan dari pemerintah pusat kepada daerah otonom untuk melaksanakan sebagian urusan pemerintahan yang menjadi kewenangan pemerintah pusat atau dari pemerintah paerah provinsi kepada paerah kabupaten atau kota untuk melaksanakan sebagian urusan pemerintahan yang menjadi kewenangan daerah provinsi.

Peraturan Pemerintah Republik Indonesia Nomor 18 Tahun 2016 Tentang Perangkat Daerah pasal 22 mengatur bahwa Perangkat Daerah yang melaksanakan urusan pemerintahan bidang pendidikan dan urutan pemerintahan yang hanya diotonomikan kepada daerah provinsi dapat dibentuk cabang dinas pendidikan kabupaten atau kota. 
Di sisi lain, surat edaran Mendikbud No. 6/2016 menyarankan untuk memilih opsi tugas pembantuan dengan pertimbangan: efisiensi karena tidak harus membentuk kantor baru, SDM yang menangani sudah tersedia, menjamin keberlangsungan hubungan kerja antara provinsi dan kabupaten atau kota, dan sebagai alternatif solusi keinginan kabupaten atau kota untuk tetap dapat berperanserta dalam penanganan pendidikan menengah.

Walaupun informan lebih banyak yang mengusulkan untuk memilih model membuka UPP di setiap wilayah, tapi ada peluang untuk menerapkan model tugas pembantuan. Dipilihnya alternatif membentuk UPP di setiap wilayah karena beberapa kabupaten atau kota menolak untuk secara bersama-sama mengelola pendidikan menengah dengan model tugas pembantuan.

Jika dianalisis dari penolakan pemerintah kabupaten atau kota mengalihkan pengelolaan pendidikan ke pemerintah provinsi, ini sebuah pertanda bahwa pemerintah kabupaten atau kota memiliki keingingan untuk terus mengelola pendidikan menengah. Keinginan ini memiliki peluang untuk diterapkan secara bersama-sama dengan pemerintah provinsi dalam mengelola pendidikan menengah.

Keempat model pengelolaan pendidikan menengah dianalisis mengguna-kan payoff table yang telah dimodifikasi seperti tampak pada tabel 1. 
Tabel 1

Analisis Manfaat Model Manajemen Pendidikan Menengah di Jawa Tengah

\begin{tabular}{|c|c|c|c|c|}
\hline $\begin{array}{l}\text { Faktor Yang } \\
\text { Dipertimbangkan }\end{array}$ & $\begin{array}{c}\text { Manajemen } \\
\text { Terpusat di } \\
\text { Kantor Provinsi }\end{array}$ & $\begin{array}{l}\text { Manajemen } \\
\text { dengan } \\
\text { Membuka } \\
\text { Kantor di } \\
\text { Setiap } \\
\text { Kabupaten }\end{array}$ & $\begin{array}{l}\text { Manajemen } \\
\text { dengan } \\
\text { Membuka UPP } \\
\text { di } 6 \text { Wilayah } \\
\text { Eks } \\
\text { Karesidenan }\end{array}$ & $\begin{array}{l}\text { Manajemen } \\
\text { dengan } \\
\text { Membentuk } \\
\text { Tugas } \\
\text { Pembantuan }\end{array}$ \\
\hline 1. Ketersediaan Sarpras & $\begin{array}{l}\text { - Cukup } \\
\text { tersedia lahan } \\
\text { dan gedung } \\
(+) \\
\text { - Cukup } \\
\text { tersedia } \\
\text { sarana (+) }\end{array}$ & $\begin{array}{l}\text { - Tidak tersedia } \\
\text { lahan \& } \\
\text { gedung (-) } \\
\text { - Tidak tersedia } \\
\text { sarana (-) }\end{array}$ & $\begin{array}{l}\text { - Cukup } \\
\text { tersedia lahan } \\
\text { \& gedung di } \\
\text { setiap eks } \\
\text { karesidenan } \\
(+) \\
\text { - Cukup } \\
\text { tersedia } \\
\text { sarana }(+) \\
\end{array}$ & $\begin{array}{l}\text { - Cukup } \\
\text { tersedia lahan } \\
\text { dan gedung } \\
(+) \\
\text { - Cukup } \\
\text { tersedia } \\
\text { sarana (+) }\end{array}$ \\
\hline $\begin{array}{l}\text { 2. Ketersediaan SDM yang } \\
\text { kompeten }\end{array}$ & $\begin{array}{l}\text { - Tidak cukup } \\
\text { tersedia SDM } \\
\text { yang } \\
\text { kompeten (-) }\end{array}$ & $\begin{array}{l}\text { - Tidak cukup } \\
\text { tersedia SDM } \\
\text { yang } \\
\text { kompeten (-) }\end{array}$ & $\begin{array}{l}\text { - Tidak cukup } \\
\text { tersedia SDM } \\
\text { yang } \\
\text { kompeten (-) }\end{array}$ & $\begin{array}{l}\text { - Sangat cukup } \\
\text { SDM yang } \\
\text { kompeten } \\
(++)\end{array}$ \\
\hline $\begin{array}{l}\text { 3. Menjaga Hubungan Kerjasama } \\
\text { dg Kab/Kota }\end{array}$ & $\begin{array}{l}\text { - Sangat tidak } \\
\text { cukup terjaga } \\
\text { hubungan }(--)\end{array}$ & $\begin{array}{l}\text { - Tidak cukup } \\
\text { terjaga } \\
\text { hubungan (- } \\
\text { ) }\end{array}$ & $\begin{array}{l}\text { - Tidak cukup } \\
\text { terjaga } \\
\text { hubungan (-) }\end{array}$ & $\begin{array}{l}\text { - Sangat cukup } \\
\text { terjaga } \\
\text { hubungan } \\
(++)\end{array}$ \\
\hline $\begin{array}{l}\text { 4. Mengakomodasi keinginan } \\
\text { kab/kota untuk berpartisipasi } \\
\text { dalam pengelolaan pendidikan } \\
\text { menengah }\end{array}$ & $\begin{array}{l}\text { - Sangat tidak } \\
\text { cukup bisa } \\
\text { berpartisipasi } \\
(--)\end{array}$ & $\begin{array}{l}\text { Tidak cukup } \\
\text { berpartisipasi } \\
(-)\end{array}$ & $\begin{array}{l}\text { - Tidak cukup } \\
\text { berpartisipasi } \\
(-)\end{array}$ & $\begin{array}{l}\text { - Sangat cukup } \\
\text { berpartissipas } \\
\text { i (+) }\end{array}$ \\
\hline $\begin{array}{l}\text { 5. Efisiensi Operasional } \\
\text { Pendidikan } \\
\end{array}$ & $\begin{array}{l}\text { - Sangat tidak } \\
\text { efisien }(--)\end{array}$ & $\begin{array}{l}\text { - Sangat tidak } \\
\text { efisien }(--)\end{array}$ & $\begin{array}{l}\text { - Cukup efisien } \\
(+)\end{array}$ & $\begin{array}{l}\text { - Sangat cukup } \\
\text { efisien }(++)\end{array}$ \\
\hline $\begin{array}{l}\text { 6. Kemudahan Operasional } \\
\text { Pendidikan }\end{array}$ & $\begin{array}{l}\text { Sangat tidak } \\
\text { mudah (--) }\end{array}$ & $\begin{array}{l}\text { Sangat tidak } \\
\text { mudah (--) }\end{array}$ & $\begin{array}{l}\text { - Mudah dalam } \\
\text { operasional } \\
(+)\end{array}$ & $\begin{array}{l}\text { - Sangat mudah } \\
\text { dalam } \\
\text { operasional } \\
(++)\end{array}$ \\
\hline Total Manfaat & $\begin{array}{l}\quad+=2 \\
-=9 \\
\text { Final: }-7\end{array}$ & $\begin{array}{l}\quad+=0 \\
-=9 \\
\text { Final: }-9\end{array}$ & $\begin{array}{l}+=4 \\
-=3 \\
\text { Final: } 1\end{array}$ & $\begin{array}{c}+=11 \\
-\quad=0 \\
\text { Final: } 11\end{array}$ \\
\hline Kesimpulan (rank) & 3 & 4 & 2 & 1 \\
\hline
\end{tabular}

Keterangan:

$(++)$ sangat cukup,

(+) cukup,

(--) sangat tidak,

(-) tidak

Positif/+ = menambah manfaat

Negatif/- = mengurangi manfaat 
Berdasarkan tabel 1 di atas diketahui yang paling memberi manfaat dalam mengelola pendidikan menengah adalah model tugas pembantuan yaitu memiliki nilai positif 11 dengan nilai negatif 0 . Sementara itu alternatif membuka UPP disetiap wilayah eks karesidenan memiliki nilai positif 4 dan memiliki nilai negatif 3. Alternatif membuka kantor hanya di kantor provinsi saja dan membuka kantor di setiap kabupaten atau kota sama-sama memiliki nilai negatif 9. Maka jelas sekali bahwa model pengelolaan pendidikan menengah yang disarankan adalah model tugas pembantuan.

\section{SIMPULAN DAN SARAN}

\section{Simpulan}

\section{Harapan Pengalihan Pengelolaan}

Pendidikan Menengah. Setelah pengelolaan pendidikan menengah dialihkan dari pemerintah kabupaten atau kota ke pemerintah provinsi banyak harapan yang muncul dari para pemangku kepentingan pendidikan. Harapan tersebut antara lain agar dapat meningkatkan mutu pendidikan, akses dan pemerataan pendidikan, peningkatan kesejahteraan dan profesionalisme pendidik dan tenaga kependidikan.

Para guru PNS yang bertugas di satuan pendidikan menengah akan lebih sejahtera karena selain mendapatkan gaji rutin mereka juga akan mendapatkan Tambahan Penghasilan Pegawai (TPP). Bagi guru yang sudah memiliki sertifikat pendidik, mereka juga akan mendapatkan tunjangan profesi guru (TPG). Artinya guru PNS akan semakin sejahtera.

\section{Tantangan Pengelolaan Pendidikan} Menengah. Beberapa tantangan yang muncul terutama dari pemerintah kabupaten atau kota yang memiliki kemampuan untuk pendanaan pendidikan dari APBD kabupaten atau kota. Tantangan itu muncul karena adanya kekhawatiran pengelolaan pendidikan menengah di tingkat provinsi

akan mengabaikan kesejahteraan guru non PNS dan menghilangkan pendidikan gratis hingga tingkat pendidikan menengah.
Tantangan tersebut didasarkan pada kenyataan bahwa kemampuan pemerintah provinsi untuk membiayai pendidikan menengah dipandang kurang. Padahal jumlah siswa SMA dan SMK cukup besar yang selama ini didistribusikan di tingkat kabupaten atau kota. Jika ini terjadi maka cita-cita untuk meningkatkan akses pendidikan menengah yang di Jawa Tengah baru mencapai $70 \%$ akan gagal dicapai.

Model Pengelolaan Pendidikan Menengah. Model yang paling efektif adalah model tugas pembantuan seperti yang disarankan oleh Kementerian Pendidikan dan Kebudayaan. Diikuti secara berturut-turut model manajemen dengan membentuk kantor di setiap wilayah eks karesidenan, model manajemen dikelola secara sentralistis di kantor Dinas Pendidikan di Provinsi Jawa Tengah, dan terakhir adalah model manajemen dengan membentuk kantor Dinas Pendidikan dan Kebudayaan di setiap kabupaten atau kota hanya untuk mengurus pendidikan menengah.

\section{Saran}

Hingga saat ini belum ada peraturan yang jelas bagaimana bentuk kerjasama antara pemerintah kabupaten atau kota dengan pemerintah provinsi untuk secara bersamasama mendanai pendidikan. Oleh karena itu yang paling mendesak saat ini adalah agar Pemerintah segera membuat peraturan pemerintah terutama terkait pengalokasian anggaran pendidikan di kabupaten atau kota untuk mendanai pendidikan menengah yang sudah bukan kewenangannya.

Di tingkat pemerintah daerah provinsi juga segera dibuat kebijakan pendidikan apakah dalam bentuk Peraturan Daerah atau Peraturan Gubernur. Kebijakan tersebut mencakup delapan standar nasional pendidikan jenjang pendidikan menengah. Dengan demikian para penyelenggara pendidikan baik di tingkat satuan pendidikan, dinas pendidikan dan kebudayaan kabupaten, dan dinas pendidikan dan kebudayaan provinsi bisa menjalankan tugas dan tanggung jawab ini dengan baik.

Pemerintah Provinsi Jawa Tengah saat ini telah memilih alternatif membentuk UPP di 
setiap wilayah eks karesidenan di Jawa Tengah. Alternatif ini perlu diuji coba efektivitasnya selama 1-3 tahun ke depan. Apabila dalam pelaksanaan ini mengalami berbagai kendala, maka alternatif yang disarankan adalah membentuk tugas pembantuan antara pemerintah provinsi dan kabupaten atau kota. Karena berdasarkan pembahasan di atas, tugas pembantuan adalah yang paling efektif diantara model yang lain karena memiliki nilai positif yang paling besar.

\section{DAFTAR PUSTAKA}

Aulia, Sitta. 2012. Desentralisasi Kebijakan Pendidikan (Studi Tentang Pelaksanaan Wajib Belajar 12 Tahun Di Kota Surabaya Pada Tingkat Pendidikan Menengah dan Kejuruan). Jurnal Politik Muda. 2 (1), 204-216.

Drummond, H., 1993. Effective Decision Making: A Practical Guide for Management. London: Kogan Page Limited.

Harrison, E.F., 1992, The Managerial Decision-Making Process. Boston: Houghton Miffin Company.

Hoy, W.K dan Miskel, C.G. 2014. Administrasi Pendidikan: Teori, Riset, dan Praktik. Yogyakarta: Pustaka Pelajar (terjemahan).

Instruksi Menteri Dalam Negeri Nomor 061/2911/SJ Tahun 2016 tentang Tindak Lanjut Peraturan Pemerintah Nomor 18 Tahun 2016 tentang Perangkat Daerah.
Lestari, D. A. dan Susena, E., 2014. Analisis Pendidikan Gratis Di SMA - SMK Di Surakarta Menuju Pendidikan Indonesia Yang Berkeadilan. Jurnal Sainstech Politeknik Indonusa Surakarta. 1 (2), 19.

Peraturan Pemerintah Republik Indonesia Nomor 18 Tahun 2016 tentang Perangkat Daerah.

Sumardjoko, B dan Prasetyo, A. 2016. Pengembangan Profesionalisme Guru SMA, MA, dan SMK Muhammadiyah Sukoharjo Jawa Tengah. Varia Pendidikan. 28 (1), 77-89.

Surat Edaran Menteri Pendidikan dan Kebudayaan Nomor 6 Tahun 2016 tentang Pedoman Organisasi Perangkat Daerah Bidang Pendidi-kan Dan Kebudayaan.

Suwandi, 2016. Analisis Studi Kebijakan Pengelolaan Guru SMK Dalam Rangka Peningkatan Mutu Pendidi-kan, Jurnal Ilmiah Pendidikan Teknologi dan Kejuruan . 23 (1), 90-100.

Undang-Undang Republik Indonesia Nomor 23 Tahun 2014 tentang Pemerintahan Daerah.

Undang-Undang Republik Indonesia Nomor 32 Tahun 2004 tentang Pemerintahan Daerah.

Undang-Undang Republik Indonesia Nomor 22 Tahun 1999 tentang Pemerintahan Daerah. 